\title{
Stonehenge Triangle
}

\author{
Anđelko Đermek
}

This paper describes a sacred triangle in a landscape of prehistoric England that was constructed around 2400 BC. The triangle consists of three henges: Stonehenge, Woodhenge and Bluestonehenge. In form it is a right isosceles triangle lined in respect to $E-W$ and N-S lines.

Keywords: myth in space, archeoastronomy, Stonehenge, Bluestonehenge, Woodhenge

This paper approaches the most well-known sacred landscape structure of prehistoric England with the background of the recent research of analogue structures of pre-Christian Slavs. The ancient Slavs positioned their sacred sites in a tripartite structures (Pleterski 1996) that were related to the central Slavic myth of a divine battle between a thunder god and his underworld opponent (Katičić 2003-2011). A substantial number of sacred triangles has already been described in Croatia, Slovenia, Austria and Germany (Pleterski 1996; Belaj 2007, Đermek 2010). These triangles probably give enough evidence to support the claim that the ancient Slavs positioned their sacred sites in a way that the angles between lines connecting pairs of sites have astronomical significance (usually refer the zenith and azimuth angles which the sun takes through the annual cycle). Very often in the observed triangles among some of the sides appears the ratio of $1: \sqrt{ } 2$. There exist some indications that the distances between sacred sites were also important. They might have been measured using the projections of right isosceles triangles on the horizontal plane (Đermek 2012, 2013).

The assumption is that the sacred landscape structures of prehistoric England are comparable to their counterparts among prehistoric Slavs despite a huge difference in timespan. The Stonehenge World Heritage site was created by UNESCO in 1986. English archaeologists recently started to examine Stonehenge and surrounding landscape as a whole: "Only later did the more complex concentric architecture of the Southern Circle and Woodhenge develop, at a time when the former came to be physically linked to Stonehenge in a new and grand design that drew the entire landscape together" (Parker Pearson et al. 2008, p. 164). Professor Parker Pearson conjectured in his book that Stonehenge, Durrington Walls with nearby Woodhenge and Bluestonehenge form a funerary complex or landscape in which human remains made a literal and metaphorical journey from the land of the living in the Durrington Walls area to the land of the dead along a funerary processional route from the River Avon into Stonehenge for burial (Parker Pearson 2012). 
An important finding in 2008 and 2009 has allowed progress in understanding the whole landscape structure. It was a discovery of a prehistoric henge and stone circle monument by the Stonehenge Riverside Project south-east of Stonehenge, very close to the River Avon (Parker Pearson et al. 2010). ${ }^{1}$ The monument was named Bluestonehenge. Its outer henge is about $25 \mathrm{~m}$ in diameter and was built around $2400 \mathrm{BC}{ }^{2}$ The stone circle which is just less than $10 \mathrm{~m}$ in diameter was built around 3400-2500 BC. ${ }^{3}$ Nine stone holes were identified, part of a circle of about 25 standing stones, ${ }^{4}$ which now are missing. The imprints of the stones' bases and the shapes of the sockets indicate that these match with the dimensions of the bluestones in the inner oval at Stonehenge. The first phase of Stonehenge is the outermost ring consisting of 56 Aubrey Holes. It is suggested that those holes originally held bluestones, which were moved to the centre of Stonehenge comprising a total of about 80 stones around 2500 BC.The extra 24 stones could be the missing stones from Bluestonehenge. ${ }^{5}$ Bluestonehenge is linked to Stonehenge itself by "the Stonehenge Avenue", which was dug around 2400 BC, ${ }^{6}$ probably simultaneously with the outer Bluestonehenge henge. From Stonehenge's north-east entrance, the Stonehenge Avenue leads towards the direction of midsummer sunrise for about $500 \mathrm{~m}$, before turning towards the river Avon, where it reaches Bluestonehenge. The avenue consists of two parallel ditches, about $20 \mathrm{~m}$ apart, with banks on both sides. The first $500 \mathrm{~m}$ of the avenue ditches stretches alongside a pair of natural chalk ridges whose azimuth is about $50^{\circ}$. It looks as if the builders had positioned Stonehenge onto the end of a natural phenomenon, which is coincidental with the midwinter sunset in one direction and the midsummer sunrise in the other.

1 Exclusive report on "Bluestonehenge" by English archaeologists Mike Parker Pearson, Joshua Pollard, Julian Thomas and Kate Welham (Parker Pearson, Pollard, Thomas, Welham 2010).

2 "A second antler pick had been discarded on the ramp of one of the stoneholes after the stone had been removed: this has just been dated to 2469-2286BC. It is not possible to be sure whether the pick was used to remove the stone, or slightly later in digging a shallow ditch into the top of the circle of robbed-out stoneholes. This radiocarbon date does, however, demonstrate that one stone, and probably the whole circle, was removed around or before that date - at about the time of the construction of the henge" (Parker Pearson et al. 2010).

3 "The circle's construction can be dated by two flint chisel arrowheads (a style used around 3400-2500 BC) from the packing of the stoneholes" (Parker Pearson et al. 2010).

4 "Assuming the nine excavated stoneholes and the curvature of their plan are representative of the complete arrangement, we can propose that it would have consisted of 25 monoliths in a $10 \mathrm{~m}$ diameter circle" (Parker Pearson et al. 2010).

5 "Stonehenge was massively rebuilt around $2500 \mathrm{BC}$ (when the sarsen circle and trilithons were erected), and renovated again around $2200 \mathrm{BC}$. The 56 Aubrey Hole bluestones were rearranged in two settings within the sarsens, together with an estimated further 23 to 33 bluestones from somewhere else. Were the monoliths from West Amesbury - Bluestonehenge - the additional stones?" (Parker Pearson et al. 2010).

6 "While confirming that these ditches were dug around $2400 \mathrm{BC}$, after the sarsens were put up at Stonehenge (estimated to be between 2580 and $2470 \mathrm{BC}$ ), we noticed something unusual. Or rather our environmental specialists, Mike Allen and Charly French, did. The avenue ditches were dug alongside a pair of natural chalk ridges whose orientation was coincidentally on the midsummer sunrise in one direction and the midwinter sunset in the other. In 2009, GT Frontline, a Dutch ground-penetrating radar team, confirmed the presence of the two parallel ridges and mapped a third, equally-spaced parallel ridge to the east. It now looked as if the builders of the first Stonehenge had added their stone circle and cremation enclosure onto the end of a remarkable natural phenomenon, where the sun's solstitial extremes were apparently marked by the contours of the land." (Parker Pearson et al. 2010). 
The third prehistoric henge that is situated north-east of Stonehenge was discovered 1925 and was named Woodhenge. It is a monument of similar size to Stonehenge, originally made up of a series of concentric circles of wooden posts within a circular bank and ditch. The ditch has been dated to between 2400 and $2000 \mathrm{BC},{ }^{7}$ but the construction of the timber monument was probably earlier ${ }^{8}$ (Pollard 2012, p.101). The site consists of six concentric oval rings of postholes, the outermost being about 40 meters wide. They are surrounded by a single flat-bottomed ditch, and by an outer bank. The site had a single entrance from the north-northeast.

It could be surmised that all three mentioned henges very probably were contemporary, at least some period of time around 2400 BC. Thus, we are justified in proposed a deliberate spatial relationship between Stonehenge, Woodhenge and Bluestonehenge. I do not know whether the English archaeologists noticed that these three locations form a right isosceles triangle (Fig. 1 \& Fig. 2). ${ }^{9}$

From Fig. 1 it can be seen that the triangle has the interior angles of $90.17^{\circ}, 45.19^{\circ}$ and $44.64^{\circ} .^{10}$ The absolute error is less than half a degree. The sides of the triangle are $2149 \mathrm{~m}, 2170 \mathrm{~m}$ and $3058 \mathrm{~m}$, so the error in reference to the ideal right isosceles triangle is about $+-10 \mathrm{~m}$ (in an ideal case it would have the legs of $2160 \mathrm{~m}$ and the hypotenuse of $3055 \mathrm{~m}=2160 \sqrt{2}$ ). The orientation of the triangle is also very special. The angle at Stonehenge which has $45.19^{\circ}$ is halved by the E-W line into two nearly equal angles of $22.66^{\circ}$ and $22.53^{\circ}$. Consequently the segment Bluestonehenge-Woodhenge is tilted with respect to the N-S line for the value of $22.83^{\circ}$ (Fig. 1, $2 \& 3$ ).

Additionally, the line that connects Bluestonehenge and Woodhenge is generally directed towards the N-NE ditch entrance into Woodhenge (Fig. 3).

Mutual visibility between three vertices of the triangle is not possible because of King Barrow and Coneybury Ridge. The visibility between Stonehenge $(101 \mathrm{~m})$ and Woodhenge $(97 \mathrm{~m})$ was possible only because of the structures which certainly were built at those two locations and which each had to be less than 10 meters high. Furthermore, the visibility between Bluestonehenge $(69 \mathrm{~m})$ and Woodhenge was possible

\footnotetext{
7 "Woodhenge is a small annex on the south side of this monument; dates from an antler pick (BM-677 $3817 \pm 74 \mathrm{BP})$ and animal bone (BM-678 3755 $\pm 54 \mathrm{BP})$ from its ditch place its digging in the period 23942039 cal BC (Pollard 1995)" (Parker Pearson et al. 2007, p. 624).

8 "Woodhenge provides a case in point (Cunnington 1929; Pollard and Robinson 2007). The henge earthwork was constructed in the third or fourth quarter of the 3rd millennium BC (2470-2030 BC and 2340-2010 BC), while the one radiocarbon date from the timber settings (a cremation from post-hole C14, dated to 2576-2468 cal BC) suggests a mid- $3^{\text {rd }}$ millennium BC date for their construction, perhaps contemporary with that of the nearby Southern Circle. The henge itself likely belongs with a megalithic phase to the monument. The sequence is in fact more complex, perhaps beginning with a phase of Grooved Ware associated settlement which may even have pre-dated the timber rings" (Pollard 2012, p.101)

9 Precise locating of the henges was done using the Google Earth layers prepared by the Archaeology Group at Bournemouth University at http://download.bournemouth.ac.uk/apsci/srp/Seeing-BeneathStonehenge.kmz: $51^{\circ} 10^{\prime} 17.11^{\prime \prime}-1^{\circ} 47^{\prime} 52.22^{\prime \prime}$ Bluestonehenge $51^{\circ} 11^{\prime} 21.83^{\prime \prime}-1^{\circ} 47^{\prime} 08.84^{\prime \prime}$ Woodhenge $51^{\circ} 10^{\prime} 43.91^{\prime \prime}-1^{\circ} 49^{\prime} 34.30^{\prime \prime}$ Stonehenge

${ }^{10}$ Conversion of geographic coordinates into Cartesian rectangular coordinate system is performed according to the formulas for the orthographic projection (EPSG dataset coordinate operation method code 9840) with the point of origin in the centre of the triangle.
} 


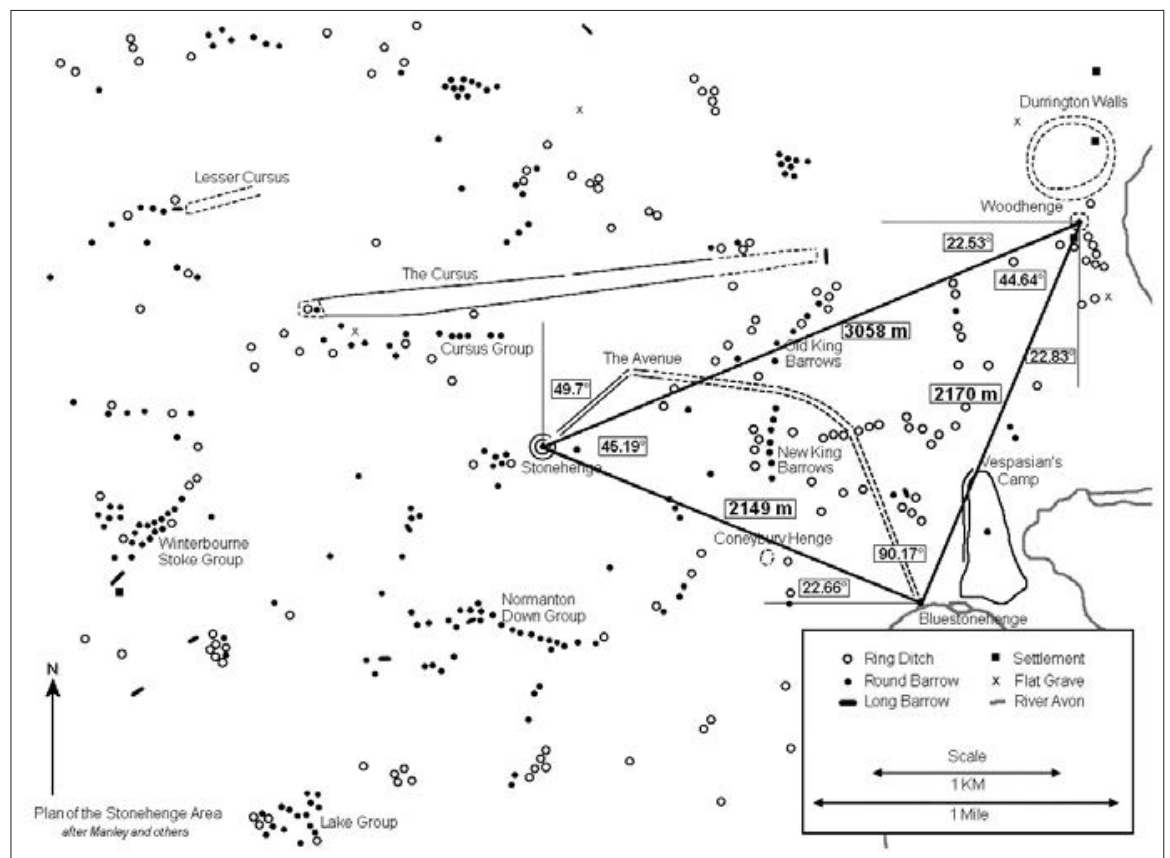

Figure 1: Stonehenge triangle superposed on a map taken at the following address: http://www.stone-circles.org. $u k /$ stone/images/hengarea.gif

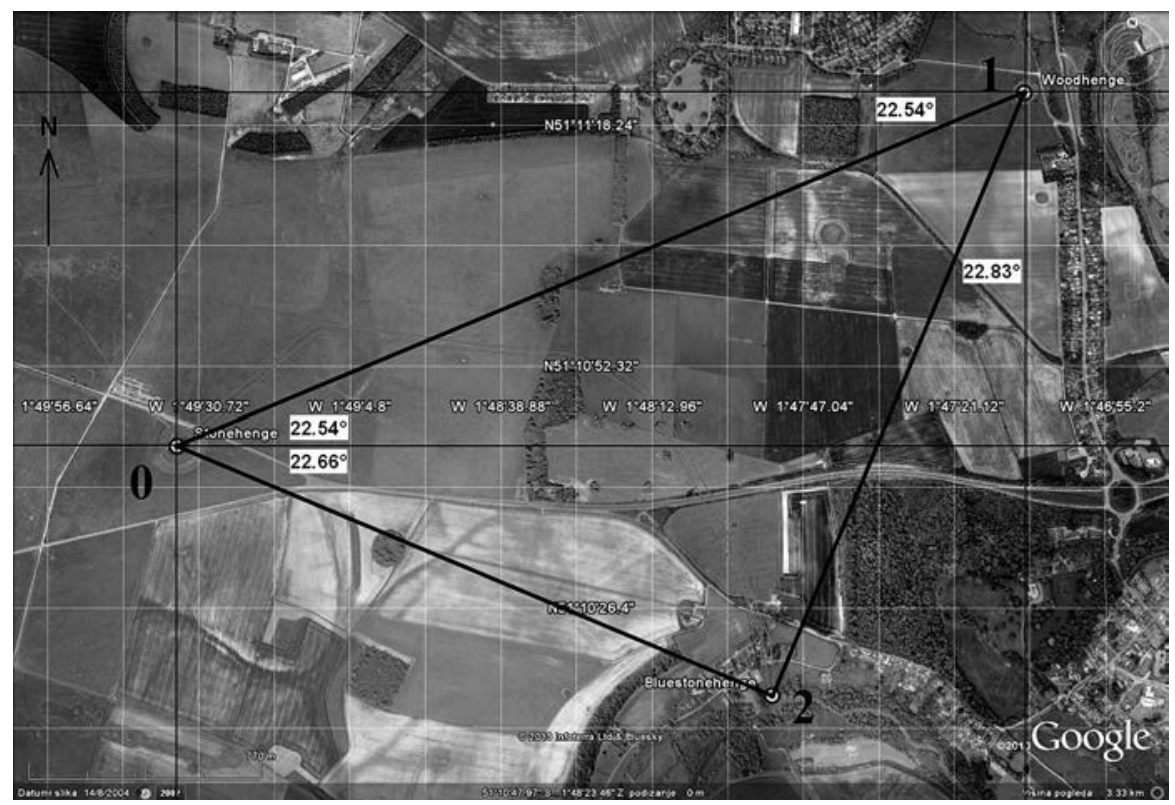

Figure 2: Stonehenge triangle superposed on the Google Earth Satellite Map (0: Stonehenge; 1: Woodhenge; 2: Bluestonehenge; Grey lines: ditches of the Avenue and of the henges) Visualization of the ditches is done with the help of Google Earth layers prepared by the Archaeology Group at Bournemouth University http://download.bournemouth.ac.uk/apsci/srp/Seeing-Beneath-Stonehenge.kmz 


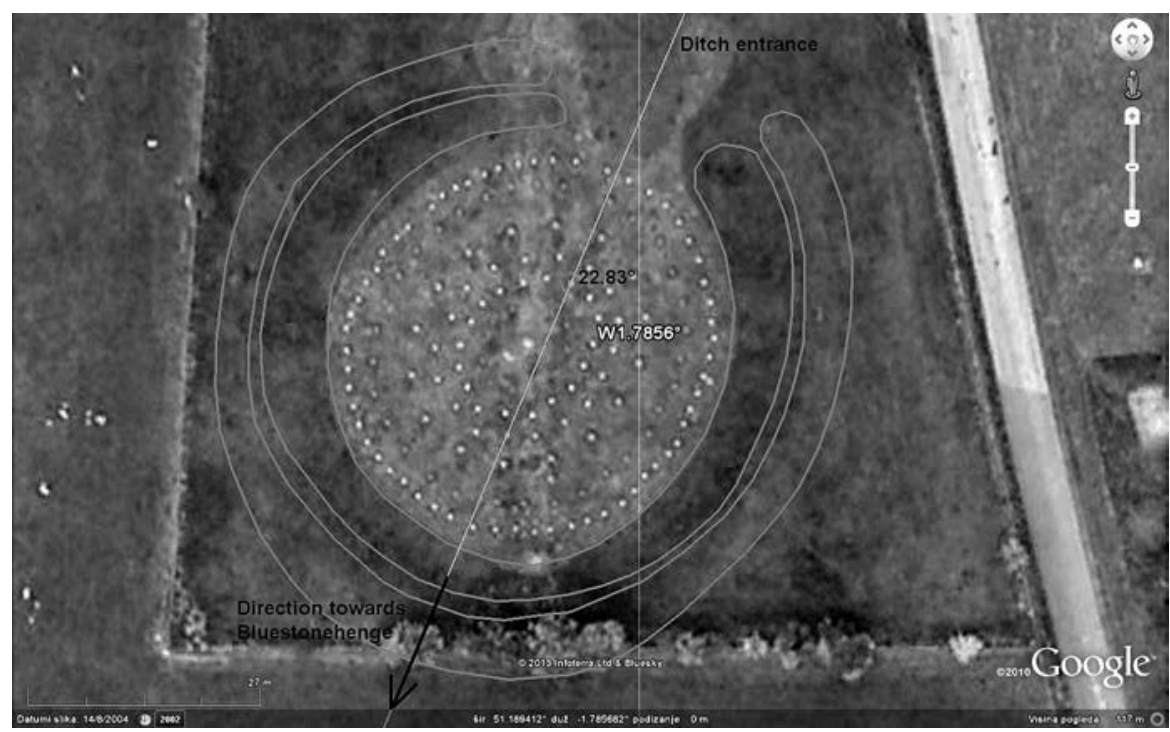

Figure 3: Woodhenge and the line Bluestonehenge-Woodhenge superposed on the Google Earth Satellite Map. Visualization of the Woodhenge ditch is done with the help of Google Earth layers prepared by the Archaeology Group at Bournemouth University http://download.bournemouth.ac.uk/apsci/srp/Seeing-Beneath-Stonehenge. $k m z$

only if the structures at their locations each had height less than 20 meters. Contrary to that, the visibility between Stonehenge and Bluestonehenge requires unrealistic heights of the structures at both sites of about 30 meters. Accordingly, we can assume that the architects did not measure only the angles between the lines connecting pairs of sites, but that they also measures the distances between them, because direct observation was not possible.

Judging from some excavation results and interpretations of the English archaeologists, ${ }^{11}$ the sanctuary at Woodhenge probably was understood to be located in the world of the living, while the sanctuary at Stonehenge was understood to be located in the imaginary world of the dead. The sanctuary at Bluestonehenge which is very close to the river held symbolic balance between these two worlds as indicated by its position at the vertex which joins the two equal legs of a right isosceles triangle.

\footnotetext{
11 "Were bodies brought here for cremation and excarnation, prior to their bones being taken for burial at Stonehenge? If so, then this is another piece of the jigsaw which puts Stonehenge as a final destination for the ancestors, reached from the domain of the living at Durrington Walls via their riverine route to the afterworld" (Parker Pearson et al. 2010).
} 


\section{References}

Belaj, Vitomir (2007): Hod kroz godinu; Pokušaj rekonstrukcije prahrvatskoga mitskoga svjetonazora. - Zagreb

Đermek, Anđelko (2010): Sustav svetišta oko Babožnice. - Studia mythologica Slavica $13,75-86$

Đermek, Anđelko (2012): Computational Analysis of the Spatial Distribution of Pre-Christian Slavic Sacred Sites. - Interdisciplinary Description of Complex Systems 10(2), 127-158.

Đermek, Anđelko (2013): Contribution to Research of Mathematical Properties of Pre-Christian Slavic Sacred Landscape Structures. - Interdisciplinary Description of Complex Systems 11(1), 71-85.

Katičić, Radoslav (2003): Die Hauswirtin am Tor : auf den Spuren der großen Göttin in Fragmenten slawischer und baltischer sakraler Dichtung. - Frankfurt am Main.

Katičić, Radoslav (2008): Božanski boj; Tragovima svetih pjesama naše pretkršćanske starine. - Mošćenička Draga.

Katičić, Radoslav (2010): Zeleni lug; Tragovima svetih pjesama naše pretkršćanske starine. - Mošćenička Draga.

Katičić, Radoslav (2011): Gazdarica na vratima; Tragovima svetih pjesama naše pretkršćanske starine. - Mošćenička Draga.

Parker Pearson, Mike (2012): Stonehenge: Exploring the greatest Stone Age mystery. Simon \& Schuster, London.

Parker Pearson, Mike - Cleal, Ros - Pollard, Josh - Richards, Colin - Thomas, Julian Tilley, Chris - Welham, Kate - Chamberlain, Andrew - Chenery, Carolyn - Evans, Jane - Montgomery, Janet - Richards, Mike (2007): The Age of Stonehenge. - Antiquity, Vol. 81, Num. 313, 617-639.

Parker Pearson, Mike - Pollard, Joshua - Richards, Colin - Thomas, Julian - Tilley, Chris - Welham, Kate (2008): The Stonehenge Riverside Project: exploring the Neolithic landscape of Stonehenge. - Documenta Praehistorica XXXV, 153-166.

Parker Pearson, Mike - Pollard, Joshua - Thomas, Julian - Welham, Kate (2010): Newhenge. - British Archaeology 110, 14-21 (http://www.archaeologyuk.org/ba/ ba110/feat1.shtml).

Pleterski, Andrej (1996): Strukture tridelne ideologije v prostoru pri Slovanih. - Zgodovinski časopis 50(2), 163-185.

Pollard, Joshua (1995): Inscribing space: formal deposition at the later Neolithic monument of Woodhenge, Wiltshire. - Proceedings of the Prehistoric Society 61, 137-56.

Pollard, Joshua (2012): Living with Sacred Spaces: The Henge Monuments of Wessex. - Enclosing the Neolithic, Recent studies in Britain and Europe, Archaeopress, Oxford, 93-107. 


\section{Trikotnik pri Stonehengeu}

\section{Anđelko Đermek}

Stonehenge, Woodhenge in Bluestonehenge so krožne strukture, ki so jih zgradili prazgodovinski prebivalci Anglije v 3. tisočletju pr. n. št. Vse te tri krožne strukture so si bile vsaj okrog 2400 pr. n. št. sočasne. Članek predlaga, da so med njimi obstajale namerne povezave. Sestavljajo pravokotni enakokraki trikotnik s koti $90,17^{\circ}$, $45,19^{\circ}$ in $44,64^{\circ}$. Stranice trikotnika merijo $2149 \mathrm{~m}, 2170 \mathrm{~m}$ in $3058 \mathrm{~m}$, kar za približno $10 \mathrm{~m}$ odstopa od idealno pravilnih dolžin stranic. Tudi usmerjenost trikotnika je nekaj posebnega. Smer zahod - vzhod razpolavlja kot trikotnika pri Stonehengeu, ki meri $45,19^{\circ}$, na dva skoraj enaka kota $22,66^{\circ}$ in $22,53^{\circ}$. Ta dva ustrezata kotu $22,83^{\circ}$, ki ga oklepa stranica trikotnika, ki povezuje Bluestonehenge in Woodhenge in se ujema $s$ smerjo vhoda v Woodhenge, s smerjo sever - jug. 
